\title{
Modulation of Amyloidogenic Peptide Aggregation by Photoactivatable CO-Releasing Ruthenium(II) Complexes
}

\author{
Daniele Florio ${ }^{1}$, Maria Cuomo ${ }^{1}$, Ilaria Iacobucci ${ }^{2,3}{ }^{\circledR}$, Giarita Ferraro ${ }^{4}$, Ahmed M. Mansour ${ }^{5}{ }^{(0)}$, \\ Maria Monti ${ }^{2,3}{ }^{(1)}$, Antonello Merlino ${ }^{2}(\mathbb{1})$ and Daniela Marasco ${ }^{1, *(\mathbb{C}}$ \\ 1 Department of Pharmacy, University of Naples Federico II, 80134 Napoli, Italy; \\ floriodaniele1@gmail.com (D.F.); cuomo.maria97@gmail.com (M.C.) \\ 2 Department of Chemical Sciences, University of Naples Federico II, 80126 Napoli, Italy; \\ ilaria.iacobucci@unina.it (I.I.); montimar@unina.it (M.M.); antonello.merlino@unina.it (A.M.) \\ 3 CEINGE Biotecnologie Avanzate S.c.a r.l., University of Naples Federico II, 80145 Napoli, Italy \\ 4 Department of Chemistry Ugo Schiff, University of Florence, 50019 Sesto Fiorentino (FI), Italy; \\ giarita.ferraro@gmail.com \\ 5 Department of Chemistry, Faculty of Science, University of Cairo, Gamma street, Giza 12613, Egypt; \\ mansour@sci.cu.edu.eg \\ * Correspondence: daniela.marasco@unina.it; Tel.: +3908-1253-4607
}

Received: 9 July 2020; Accepted: 28 July 2020; Published: 29 July 2020

\begin{abstract}
Three $\mathrm{Ru}(\mathrm{II})$-based CO-releasing molecules featuring bidentate benzimidazole and terpyridine derivatives as ligands were investigated for their ability to modulate the aggregation process of the second helix of the C-terminal domain of nucleophosmin 1, namely nucleophosmin 1 (NPM1) 264-277, a model amyloidogenic system, before and after irradiation at $365 \mathrm{~nm}$. Thioflavin T (ThT) binding assays and UV/Vis absorption spectra indicate that binding of the compounds to the peptide inhibits its aggregation and that the inhibitory effect increases upon irradiation (half maximal effective concentration $\left(\mathrm{EC}_{50}\right.$ ) values in the high micromolar range). Electrospray ionization mass spectrometry data of the peptide in the presence of one of these compounds confirm that the modulation of amyloid aggregation relies on the formation of adducts obtained when the Ru compounds react with the peptide upon releasing of labile ligands, like chloride and carbon monoxide. This mechanism of action explains the subtle different behavior of the three compounds observed in ThT experiments. Overall, data support the hypothesis that metal-based CO releasing molecules can be used to develop metal-based drugs with potential application as anti-amyloidogenic agents.
\end{abstract}

Keywords: modulators of amyloid peptide aggregation; metallodrugs; ruthenium(II) compounds; CO releasing molecules

\section{Introduction}

Ruthenium complexes represent an important class of metal-based agents with multiple potential applications in different diseases both in therapy and in diagnosis [1]. The antineoplastic function of ruthenium complexes is based on their interactions with DNA [2], mitochondria, and endoplasmic reticulum of cells [3,4], as well as with proteins involved in crucial cellular pathways [5]; they are able to induce tumor cell apoptosis, autophagy, and inhibition of angiogenesis [6,7]. Furthermore, they can be used as specific tumor biomolecular probes and as phototherapeutic agents [8].

In amyloid diseases $[9,10], \mathrm{Ru}(\mathrm{II})$-complexes have been used for both diagnostic and therapeutic purposes [11]. In general, $\mathrm{Ru}(\mathrm{II})$ and $\mathrm{Ru}(\mathrm{III})$ complexes interact with peptides of different lengths 
and proteins forming adducts with different stoichiometries [5]. The formation of adducts with amyloidogenic peptides affects their toxicity and propensity to aggregate [11,12].

In pioneering studies, several well-known anticancer Ru(III) complexes, as NAMI-A [13] (imidazolium [trans- $\mathrm{RuCl}_{4}\left({ }^{1} \mathrm{H}\right.$-imidazole)(dimethylsulfoxide-S)]), KP1019 [14] (indazolium [trans- $\left.\mathrm{RuCl}_{4}\left({ }^{1} \mathrm{H} \text {-indazole }\right)_{2}\right]$ ) and PMRU20 (2-aminothiazolium [trans- $\left.\mathrm{RuCl}_{4}(2 \text {-aminothiazole })_{2}\right]$ ), were investigated as in vitro inhibitors of $A \beta_{1-42}$. It has been demonstrated that PMRU20 is highly effective in protecting cells from $A \beta_{1-42}$ toxicity. Electrospray ionization-mass spectrometry (ESI-MS) analysis, evidenced the formation of adducts formed upon reaction of the compound with the peptide and thioflavin $\mathrm{T}$ assay, revealed that the presence of the Ru complex greatly reduces peptide aggregation in vitro [15]. Derivatives of NAMI-A and PMRU20 exhibit enhanced affinity toward $\mathrm{A} \beta_{1-40}$ [16]. The complex fac-[Ru(CO) ${ }_{3} \mathrm{Cl}_{2}\left(\mathrm{~N}^{1}-\right.$ thz $\left.)\right]$ (thz $=1$,3-thiazole) binds the $1-28$ fragment of the $\beta$-amyloid peptide [17]. A tetradentate $\mathrm{Ru}(\mathrm{II})$ complex containing a tris(2-pyridylmethyl)amine (tpa) ligand acts as inhibitor of $A \beta_{1-40}$ aggregation in vitro [18]. Similar effects were observed in the context of human Islet Amyloid Polypeptide (hIAPP) amyloid process: NAMI-A, [Ru(bipy)Cl $\left.l_{4}\right]$ and $\left[\mathrm{Ru}\right.$ (bipy) $\left.{ }_{2} \mathrm{Cl}_{2}\right]$ (bipy $=2,2^{\prime}$-bipyridine) bind hIAPP, significantly altering its aggregative features [19]. The complex [Ru(bipy)(met) $\left.)_{2}\right] \cdot 3 \mathrm{H}_{2} \mathrm{O}$ (met = methionine) inhibits the fibril formation of hIAPP and depolymerizes mature fibrils [20]. Binuclear Ru complexes are able to interfere with hIAPP aggregation causing the formation of nanometric particles with reduced $\beta$-sheet content and cytotoxicity, exhibiting a greater affinity with respect to the corresponding mononuclear Ru complexes, likely due to synergic contribution of the second center acting as promising metallodrugs in the field of T2DM (Type 2 Diabetes Mellitus) [21]. A similar synergistic effect was shown by heterobimetallic $\mathrm{Ru}(\mathrm{II})-\mathrm{Au}(\mathrm{I})$ complexes bearing different spacer lengths (4-8 polyethylene glycol units) able to bind to a fragment of the amyloid $\beta_{1-16}$ in accordance with the binding abilities of parent drugs, RAPTA-C [22] and auranofin [23,24].

Recently, the use of luminescent transition metal complexes as non-conventional probes of amyloid formation has been also explored: the idea is to exploit their long-lived fluorescent life-times due to the spin-orbit coupling promoted by heavy metal ions [25]. For example, it has been shown that the luminescent dipyridophenazine (dppz) $R u(I I)$ complex $\left[\mathrm{Ru}(\mathrm{bipy})_{2}(\mathrm{dppz})\right]^{2+}$ can be used to monitor $\mathrm{A} \beta$ fibrillization. This compound is not photoluminescent in aqueous solution nor in the presence of monomeric $A \beta$, but it presents a strong photoluminescence in presence of $A \beta$ aggregates. Indeed, the interaction of $\left[\mathrm{Ru}(\mathrm{bipy})_{2}(\mathrm{dppz})\right]^{2+}$ with $\mathrm{A} \beta$ fibrils changes the polarity of the environment of the complex causing the enhancement of luminescence [26]. A similar behavior was exhibited by [Ru(dmbpy)(dcbpy)(dppz)] $\left(\mathrm{dmbpy}=4,4^{\prime}\right.$-dimethyl-2,2'-bipyridine, and dcbpy $=4,4^{\prime}$-dicorboxy-2,2'-bipyridine $)$ [27]. More recently, it has been demonstrated that a Ru-based fluorescent probe, $\left[\mathrm{Ru}(\mathrm{phen})_{2}(\mathrm{fipc})\right]^{2+}$ (phen $=1,10$-phenanthroline, fipc $=5$-fluoro- $N$-(1,10-phenanthrolin-5-yl)-1H-indole-2-carboxamide $]$, is able to interact with $A \beta$ in all forms (monomers, oligomers and fibrils) [28].

Overall, these data indicate that Ru compounds can be used alone or in combination with other metals to inhibit $\beta$-amyloid fibril formation in neurodegenerative diseases [29]. Among the $\mathrm{Ru}$ compounds to be used in this field, $\mathrm{Ru}(\mathrm{II})$ complexes that act as carbon monoxide-releasing molecules (CORMs) are particularly promising [30]. These molecules transport and release $\mathrm{CO}$ in controlled manner even if they are bound to proteins [31-34] and received particular attention as therapeutic agents for the anti-inflammatory [35] and anti-apoptotic [36] properties [37,38]. These compounds are promising for the treatment of neurodegenerative diseases since it has been shown that, at small concentration, $\mathrm{CO}$ can interfere with several crucial pathways in which dysregulation is at the basis of the disease development [39-43]. It has been also demonstrated that CORMs exhibit neuroprotective effects through a direct modulation of $A \beta_{1-42}$ aggregation in vitro [44].

On the basis of these considerations, we think that Ru-based CORMs that can be photoactivated could represent a valuable strategy for the inhibition of amyloid peptide aggregation. Herein, we studied the ability of three photoinduced $\mathrm{CO}$ releasing, $\mathrm{RuCl}_{2}(\mathrm{CO})_{2}$-based, compounds as inhibitors 
of aggregation of the peptide fragment corresponding to the helix H2 (residues 264-277) of C-terminal domain of nucleophosmin 1 (NPM1 $264-277)$. This peptide forms amyloid aggregates with $\beta$-sheet conformation and fibrillar morphology, toxic to neuroblastoma cells [45-51]. In particular, we chose three dicarbonyl $\mathrm{Ru}(\mathrm{II})$ compounds (Figure 1) functionalized with bidentate $4^{\prime}$-(2-pyridyl)-2,2':6' $2^{\prime \prime}$-terpyridine (1) [34], 2,6-bis(benzimidazole-2'-yl)pyridine (2) [52], and 1-(5-bromopentyl)phthalimide-2-(2'-pyridyl) benzimidazole (3) [53] ligands for this study.

Compound 3 exhibits interesting antifungal activity against Candida albicans and Cryptococcus neoformans in the micromolar range and is safe to the non-malignant HEK293 cell line [53]. Compounds 1-3 interact with proteins leading to the formation of adducts able to release $\mathrm{CO}$ upon UV irradiation at $365 \mathrm{~nm}[34,52,53]$.

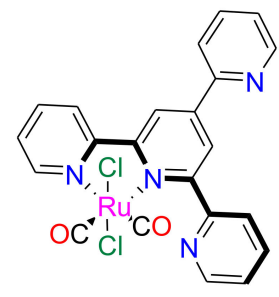

1

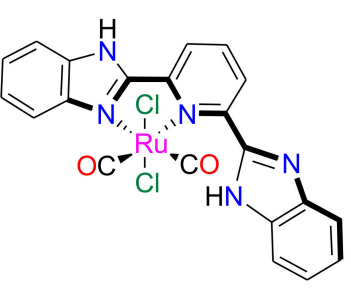

2

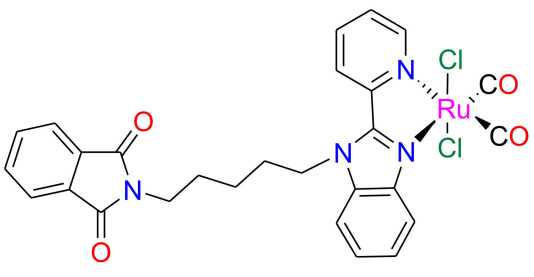

3

Figure 1. Chemical structures of the $\mathrm{Ru}(\mathrm{II})$-based PhotoCORMs investigated in this study. CORMS = carbon monoxide-releasing molecules.

\section{Results and Discussion}

\subsection{NPM1 $1_{264-277}$ Aggregation Is Suppressed by the Presence of the Investigated Ru(II) Complexes}

The effects exerted by $\mathrm{Ru}(\mathrm{II})$ complexes on the self-aggregation process of $\mathrm{NPM}_{264-277}$ were investigated through the analysis over time of Thioflavin T (ThT) fluorescence emission. In Figure 2, the overlay of fluorescence profiles for peptide alone and in the presence of the $\mathrm{Ru}$ compounds in 1:1 peptide:complex molar ratio is reported. As shown, the presence of all three metal complexes clearly induces a decrease of ThT signal when compared to that observed for the peptide alone. This finding suggests a modulation of peptide self-aggregation. At $t=0$, the non-zero values and the different fluorescence intensities of ThT, in the presence of the three compounds, suggest a potential quenching/direct binding between metal complexes and the fluorescent probe [54]. At the early stage of aggregative process, compounds $\mathbf{1}$ and $\mathbf{2}$ already act as modulators of the aggregation, while compound 3 exhibits suppression of aggregation only after $20 \mathrm{~min}$ of stirring. Indeed, for compound 3 from $t=0$ to $t=20 \mathrm{~min}$, a slight increase of ThT signal is observable even though the enhancement is slower than that shown by the peptide alone and the ThT signal reaches intensities that are significantly lower than those found in the absence of complexes. A behavior similar to that reported for compound 3 has been observed for a Pt-compound that also acts as modulators of NPM1 264-277 aggregation [55]. The different behavior of the three Ru compounds here analyzed as modulators of aggregation should be related to their structural features. Indeed, the higher hindrance of the phthalimide ligand in compound 3 could affect the kinetics of its potential interaction with the peptide; conversely, the presence of free pyridine or benzimidazole arm, ready to interact with the metal center, could facilitate the binding of compounds $\mathbf{1}$ and $\mathbf{2}$ to the peptide when compared to compound $\mathbf{3}$. These features delay the compound 3 ability to modulate the aggregation of NPM1 $1_{264-277}$ when compared to compounds 1 and 2.

At greater interval time ( $200 \mathrm{~min}$ ), the ThT fluorescence value observed for $\mathrm{NPM}_{264-277}$ in the presence of the three compounds is not far from the starting value found when the peptide is alone. This finding suggests that the compounds could interact with the monomeric form of NPM1 $264-277$ hampering the self-recognition of different peptide chains. 


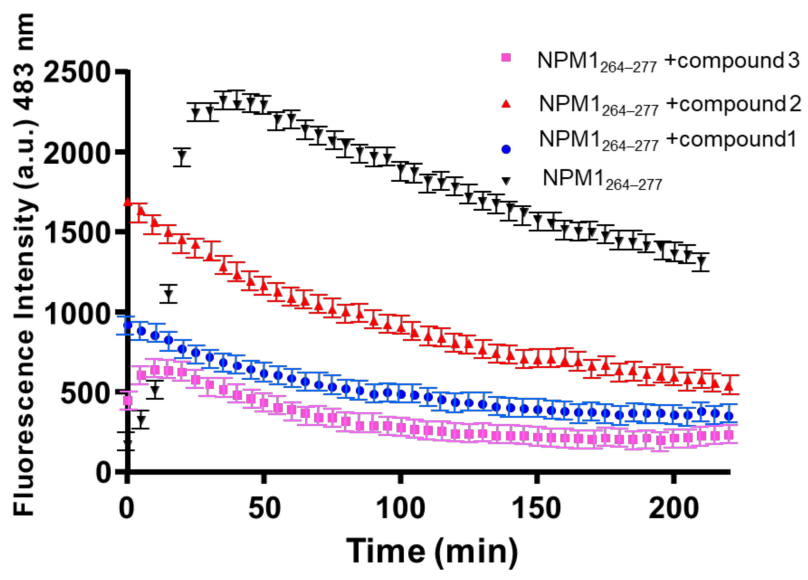

Figure 2. Overlay of time-courses of Thioflavin T (ThT) fluorescence emission intensity of nucleophosmin 1 (NPM1) $264-277$ in presence of the three $\mathrm{Ru}(\mathrm{II})$ compounds (1-3), at 1:1 peptide to metal-based compound molar ratio. Results are representative of two independent experiments.

To evaluate if the compounds are able to modulate the aggregation process of NPM1 $1_{264-277}$ upon releasing of $\mathrm{CO}$, the same ThT time-courses were registered using $\mathrm{Ru}(\mathrm{II})$ compounds that have been irradiated with a UV lamp at $365 \mathrm{~nm}$. A comparison of the behavior of irradiated and non-irradiated compounds is reported in Figure 3. The analysis of reported ThT profiles indicates that the investigated PhotoCORMs reduce the amyloid aggregation more strongly after illumination. The value of ThT fluorescence intensity observed for the samples of the peptide in the presence of the irradiated complexes is significantly lower than that observed for non-irradiated complexes. After irradiation, compound 1 also provides a faster inhibitory effect than the corresponding non-irradiated sample, as inferable from normalized signals reported in Figure S3. This may be explained considering that compound 1 releases CO faster than compounds $\mathbf{2}$ and 3, as previously discussed [34,52,53], under the same experimental conditions.

(A)

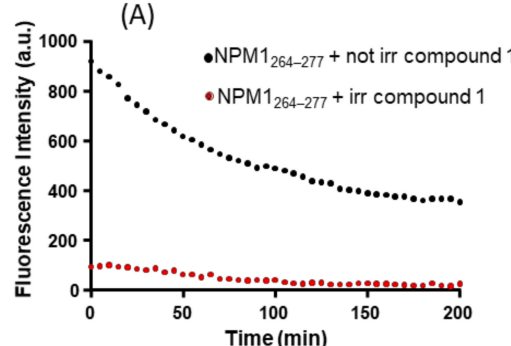

(B)

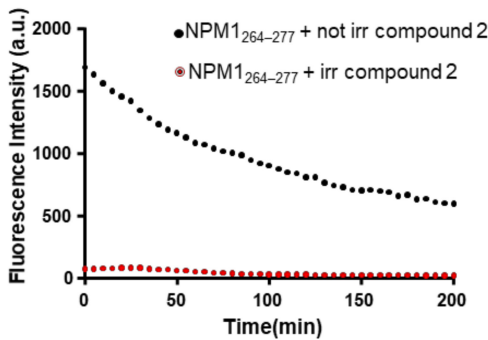

(C)

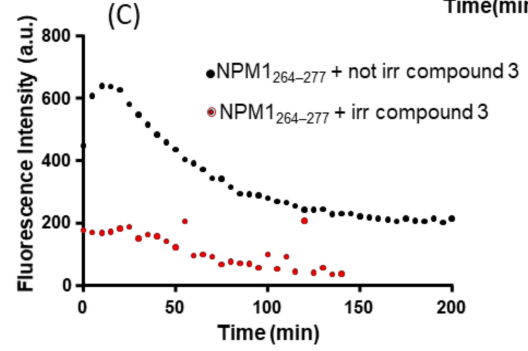

Figure 3. Overlay of time-courses of ThT fluorescence emission intensity of $\mathrm{NPM}_{264-277}$ in presence of the three $\mathrm{Ru}$ (II) complexes: (A) compound 1; (B) compound 2 (C) compound 3, at 1:1 peptide to metal-based compound molar ratio. Results are representative of two independent experiments.

\subsection{The Ligand Field of Ru(II) Complexes Changes in the Presence of NPM1 $264-277$}

Since it is known that irradiation with UV light induces release of CO from the investigated Ru-based PhotoCORMs $[34,52,53]$ and considering that the irradiated complexes act as modulators 
of the aggregation process of the amyloid peptide more efficiently than non-irradiated samples, we supposed that the mechanism at the basis of the activity of the compounds was grounded on the exchange of $\mathrm{CO}$ with a side chain of a peptide residue. To prove this hypothesis, UV-Vis absorption spectroscopy and electrospray mass spectrometry data have been collected.

The ability of NPM1 $1_{264-277}$ to perturb ligand fields of investigated CORMs was analyzed through UV/Vis absorption spectroscopy. The lack of changes in the position of Ligand to Metal Charge Transfer (LMCT) or Metal to Ligand Charge Transfer (MLCT) bands indicates a retention of symmetry around metal center, while the variations of the position and intensity of the maximum absorption wavelength suggest possible substitutions of the ligands in the coordination of $\mathrm{Ru}(\mathrm{II})$ by side chains of residues of the peptide. Since the sequence of the peptide is VEAKFINYVKNCFR, the side chains that can coordinate the Ru center are C, E, N, K, or R.

The spectra of the three $\mathrm{Ru}(\mathrm{II})$ complexes registered upon the addition of increasing amount of NPM1 $1_{264-277}$ are reported in Figure 4. In aqueous solutions, all three compounds present MLCT bands (at $\sim 330 \mathrm{~nm}$ ) with a hypsochromic shift with respect to the value observed in pure Dimethyl Sulfoxide (DMSO) (data not shown and references [34,52,53]), in agreement with what expected on the basis of previous analyses [34]. In this respect, it should be underlined that the metal compounds are soluble and stable for $24 \mathrm{~h}$ in the analyzed aqueous solutions (data not shown $[34,52,53]$ ).

The addition of NPM1 $264-277$ to the Ru compounds produces in all the cases an increase of intensity of the signal. Unfortunately, due to poor solubility of the adduct formed upon reaction of compound 1 with the peptide, it was not possible to reach saturation state when the sample is not irradiated (Figure 4E), and it was not possible to collect spectra when the sample is irradiated.

Compound 2 does not reach saturation (Figure 4A), while for compound $\mathbf{3}$ (Figure 4C), the addition of peptide allows to reach saturation at 1:3 complex: peptide molar ratio. For compound 3 , the titration allows a fit of experimental data with a saturated profile, providing an estimation of $\mathrm{EC}_{50}$ (half maximal effective concentration) $=345.4 \pm 1.0 \mu \mathrm{M}$ (inset of Figure $4 \mathrm{C}$ ) .

In the case of irradiated samples, only compound 2 reaches saturation at complex: peptide molar ratio of 1:4. For compound 2, an $\mathrm{EC}_{50}=105.3 \pm 1.1 \mu \mathrm{M}$ was estimated (inset of Figure $4 \mathrm{~B}$ ).

\subsection{ESI-MS Analysis of NPM1 $1_{264-277}$ in the Presence of the Ru Compounds}

Despite samples of NPM1 $1_{264-277}$ in the presence of the three Ru compounds were prepared and analyzed through ESI-MS, spectra have been successfully registered only in the case of the adducts formed upon reaction of compound 2 with the peptide.

ESI-MS analysis of NPM1 $1_{264-277}$ following incubation with compound 2 shows the presence of NPM1 $264-277$ both as monomer $(1770.93 \pm 0.01 \mathrm{Da})$ and as disulfide-bridged dimer $(3541.19 \pm 0.95$ Da). Both species generate adducts with compound 2 either spontaneously or after UV irradiation; for each metal compound that is bound to the peptide, a trifluoroacetate (TFA) ion, coming from the background solvent, is present. As reported in Figure 5A and Table 1, both monomeric and dimeric forms of NPM1 $1_{264-277}$ binds one molecule of compound 2 losing two chloride ions, as demonstrated by the presence of two species of $2236.37 \pm 0.94 \mathrm{Da}$ and $4005.54 \pm 0.93$ Da molecular weight, respectively. This finding suggests a bidentate mode of binding of the Ru-containing fragment to the peptide. Moreover, the NPM1 $1_{264-277}$ dimer also forms an adduct with two molecules of the metal compound $(4470.40 \pm 0.53 \mathrm{Da})$. In addition, metal compound species lacking one carbon monoxide molecule can also bind the peptide (Table 1). As demonstrated by ESI-MS analysis of the non-irradiated sample, the release of $\mathrm{CO}$ in the presence of the peptide is a process independent on irradiation. However, as expected, it is increased by UV treatment. Indeed, as reported in Figure 5B and Table 2, ESI-MS spectra display the occurrence of adducts formed by exchange of both chloride ions and one $\mathrm{CO}$ molecule, after shorter incubation time. It is important to highlight that following irradiation, the $\mathrm{CO}$ loss from the complex occurs in a complete way. The finding that the NPM1 $1_{264-277}$ dimer binds the same Ru-containing fragments when compared to the monomer suggests that the metal center 
does not coordinate the cysteine residue. Thus, E, N, K, or R are the only residues of the peptide that can be involved in the coordination of the metal containing fragment.

(A)
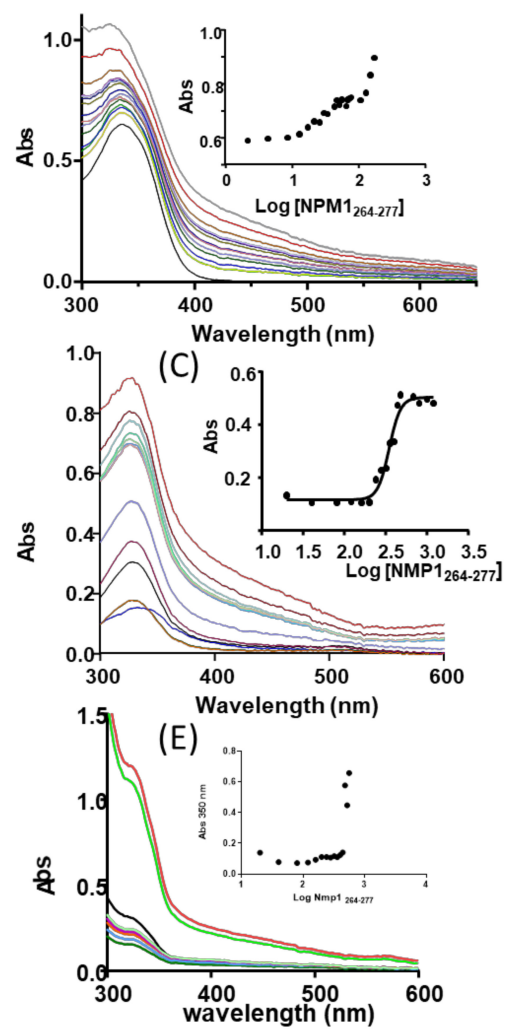

(B)

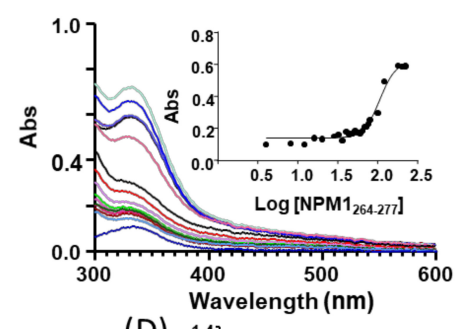

(D)

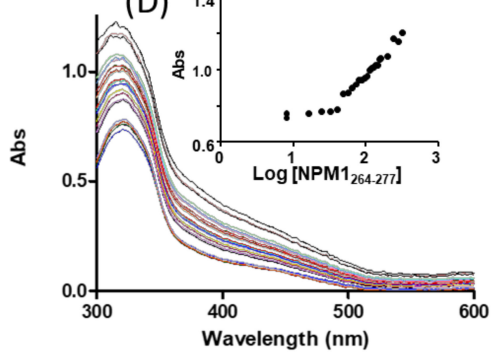

Figure 4. Absorption spectra of (A,B) compound 2, (C,D) compound $\mathbf{3}$ and (E) compound $\mathbf{1}$ in UV irradiated $(\mathbf{B}, \mathbf{D})$ and not irradiated $(\mathbf{A}, \mathbf{C}, \mathbf{E})$ preparation, upon the addition of increasing amount of $\mathrm{NPM1}_{264-277}$. As insets UV intensities at $\sim 330 \mathrm{~nm}$ versus Log concentration of NPM1 $1_{264-277}$ have been reported.

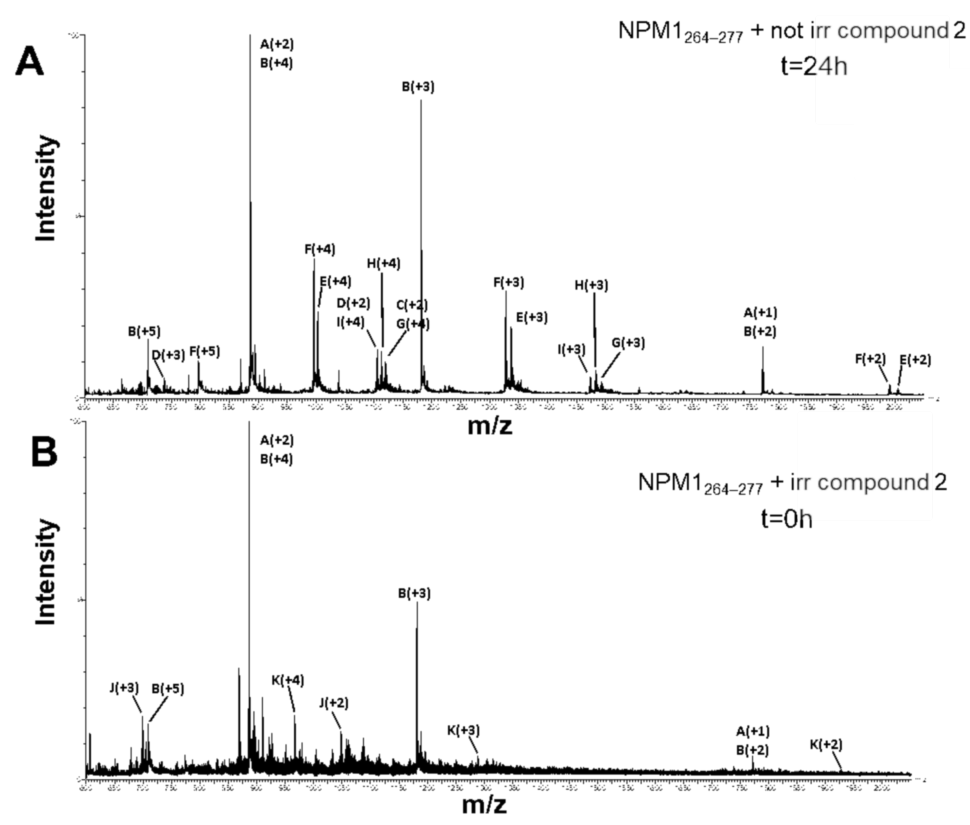

Figure 5. ESI-MS multi-charged spectra of NPM1 $264-277+$ compound 2 after $24 \mathrm{~h}$ of incubation (no irradiation) (A) and UV-irradiation upon freshly prepared sample (B). 
Table 1. ESI-MS detected species formed by NPM1 $1_{264-277}$ and compound 2 at $24 \mathrm{~h}$ of incubation. The experimental $\mathrm{m} / \mathrm{z}$ values and their charge, the experimental and theoretical molecular weight, and the corresponding species are reported. TFA: trifluoroacetate.

\begin{tabular}{|c|c|c|c|c|}
\hline$m / z$ Signal & Charge & Experimental MW & Theoretical MW & Species \\
\hline $\begin{array}{c}886.47 \\
1771.93\end{array}$ & $\begin{array}{l}A+2 \\
A+1\end{array}$ & $1770.93 \pm 0.01$ & 1770.91 & Monomer (NPM1 $\left.{ }_{264-277}(\mathrm{M})\right)$ \\
\hline $\begin{array}{c}708.83 \\
885.97 \\
1181.63 \\
1771.93\end{array}$ & $\begin{array}{l}B+5 \\
B+4 \\
B+3 \\
B+2\end{array}$ & $3541.19 \pm 0.95$ & 3539.82 & Dimer $\left(\mathrm{NPM1} 1_{264-277}(\mathrm{D})\right)$ \\
\hline $\begin{array}{c}746.78 \\
1118.72\end{array}$ & $\begin{array}{l}C+3 \\
C+2\end{array}$ & $2236.37 \pm 0.94$ & 2234.27 & $\begin{array}{c}\mathrm{NPM}_{264-277}(\mathrm{M})+1 \text { compound } 2-2 \\
\mathrm{HCl}+1 \text { TFA }\end{array}$ \\
\hline $\begin{array}{c}736.65 \\
1104.48\end{array}$ & $\begin{array}{l}\mathrm{D}+3 \\
\mathrm{D}+2\end{array}$ & $2207.28 \pm 0.48$ & 2206.26 & $\begin{array}{c}\mathrm{NPM}_{264-277}(\mathrm{M})+1 \text { compound } 2-2 \\
\mathrm{HCl}-1 \mathrm{CO}+1 \text { TFA }\end{array}$ \\
\hline $\begin{array}{l}1002.23 \\
1335.97 \\
2004.43\end{array}$ & $\begin{array}{l}E+4 \\
E+3 \\
E+2\end{array}$ & $4005.54 \pm 0.93$ & 4003.16 & $\begin{array}{c}\mathrm{NPM1}_{264-277}(\mathrm{D})+1 \text { compound } 2-2 \\
\mathrm{HCl}+1 \text { TFA }\end{array}$ \\
\hline $\begin{array}{c}796.18 \\
994.48 \\
1326.63 \\
1988.96\end{array}$ & $\begin{array}{l}F+5 \\
F+4 \\
F+3 \\
F+2\end{array}$ & $3975.64 \pm 1.08$ & 3975.15 & $\begin{array}{c}\mathrm{NPM1}_{264-277}(\mathrm{D})+1 \text { compound } 2-2 \\
\mathrm{HCl}-1 \mathrm{CO}+1 \text { TFA }\end{array}$ \\
\hline $\begin{array}{l}1118.47 \\
1491.32\end{array}$ & $\begin{array}{l}G+4 \\
G+3\end{array}$ & $4470.40 \pm 0.53$ & 4466.55 & $\begin{array}{c}\mathrm{NPM1}_{264-277}(\mathrm{D})+2 \text { compound } 2-4 \\
\mathrm{HCl}+2 \mathrm{TFA}\end{array}$ \\
\hline $\begin{array}{l}1111.71 \\
1481.64\end{array}$ & $\begin{array}{l}\mathrm{H}+4 \\
\mathrm{H}+3\end{array}$ & $4442.35 \pm 0.46$ & 4438.49 & $\begin{array}{c}\mathrm{NPM}_{264-277}(\mathrm{D})+2 \text { compound } 2-4 \\
\mathrm{HCl}-1 \mathrm{CO}+2 \text { TFA }\end{array}$ \\
\hline $\begin{array}{l}1104.23 \\
1471.97\end{array}$ & $\begin{array}{l}\mathrm{I}+4 \\
\mathrm{I}+3\end{array}$ & $4412.90 \pm 0.01$ & 4410.48 & $\begin{array}{c}\mathrm{NPM}_{264-277}(\mathrm{D})+2 \text { compound } 2-4 \\
\mathrm{HCl}-2 \mathrm{CO}+2 \text { TFA }\end{array}$ \\
\hline
\end{tabular}

Table 2. ESI-MS detected species formed by NPM1 $1_{264-277}$ with irradiated compound 2 at $0 \mathrm{~h}$ of incubation. The experimental $\mathrm{m} / \mathrm{z}$ values and their charge, the experimental and theoretical molecular weight, and the corresponding species are reported.

\begin{tabular}{|c|c|c|c|c|}
\hline$m / z$ Signal & Charge & Experimental MW & Theoretical MW & Species \\
\hline $\begin{array}{c}886.48 \\
1772.00\end{array}$ & $\begin{array}{l}A+2 \\
A+1\end{array}$ & $1770.97 \pm 0.02$ & 1770.91 & Monomer $\left(\mathrm{NPM} 1_{264-277}(\mathrm{M})\right)$ \\
\hline $\begin{array}{c}709.39 \\
885.99 \\
1180.99 \\
1771.49\end{array}$ & $\begin{array}{l}B+5 \\
B+4 \\
B+3 \\
B+2\end{array}$ & $3540.68 \pm 0.81$ & 3539.82 & Dimer (NPM1 $264-277(\mathrm{D}))$ \\
\hline $\begin{array}{c}698.31 \\
1046.99 \\
2093.92 \\
\end{array}$ & $\begin{array}{l}\mathrm{J}+3 \\
\mathrm{~J}+2 \\
\mathrm{~J}+1 \\
\end{array}$ & $2092.28 \pm 0.68$ & 2093.23 & $\begin{array}{c}\mathrm{NPM}_{264-277}(\mathrm{M})+1 \text { compound } 2-2 \\
\mathrm{HCl}-1 \mathrm{CO}\end{array}$ \\
\hline $\begin{array}{c}644.94 \\
773.39 \\
966.48 \\
1288.99 \\
1932.73\end{array}$ & $\begin{array}{l}K+6 \\
K+5 \\
K+4 \\
K+3 \\
K+2\end{array}$ & $3862.96 \pm 0.89$ & 3862.13 & $\begin{array}{c}\mathrm{NPM}_{264-277}(\mathrm{D})+1 \text { compound } 2-2 \\
\mathrm{HCl}-1 \mathrm{CO}\end{array}$ \\
\hline
\end{tabular}

\section{Materials and Methods}

\subsection{Peptide and Metal Compound Synthesis}

Acetylated and amidated peptide corresponding to NMP1 $1_{264-277}$ sequence (VEAKFINYVKNCFR) was synthesized as already reported [56]. Reagents for Solid-Phase Peptide Synthesis (SPPS)were purchased from Iris Biotech (Marktredwitz, Germany) and solvents from Romil (Dublin, Ireland). The peptide was treated with Hexafluoro-2-propanol (HFIP) (at $50 \%(v / v)$ in water), purified by RP-HPLC and identified through LC-MS. The Ru(II) complexes (Figure 1) were synthetized as 
previously described $[34,52,53]$. UV- irradiation was performed using a UV/vis hand lamp $(365 \mathrm{~nm}$, filter $145 \times 48 \mathrm{~nm}$, power $2 \times 6$ Watt, Vilber lourmat, France). In experiments with irradiated complexes, the metal compounds were irradiated, and, only successively, the peptide and, finally, ThT (for fluorescence assay) were added.

\subsection{ThT Fluorescence}

The abilities of $\mathrm{Ru}(\mathrm{II})$ complexes to interfere with amyloid aggregation of $\mathrm{NMP1}_{264-277}$ through the analysis of time-courses of thioflavin (ThT) fluorescence, at $25{ }^{\circ} \mathrm{C}$ using a Jasco FP 8300 spectrofluorometer (Tokyo, Japan), (settings: $\lambda_{\mathrm{exc}}=440 \mathrm{~nm}, \lambda_{\mathrm{em}}=483 \mathrm{~nm}$ ). Peptide and ThT concentrations were 100 and $50 \mu \mathrm{M}$, respectively, $10 \mathrm{mM}$ borate buffer at $\mathrm{pH}=9.0$, DMSO $\sim .2 \%$. Control experiments indicate that the fluorescence spectra of the metal compounds in the presence of ThT show negligible intensities. The analysis was carried out maintaining a magnetic stirring in a $10 \mathrm{~mm}$ path-length quartz cuvette. Data were reported as mean of two independent experiments.

\subsection{UV/Vis Spectroscopy}

UV/Vis spectra of the $\mathrm{Ru}(\mathrm{II})$ compounds titrated with $\mathrm{NMP} 1_{264-277}$ were registered with a Nanodrop $2000 \mathrm{c}$ of Thermo Scientific (Waltham, MA, USA) at the same temperature and buffer conditions of fluorescence assay. Titrations were carried out at a fixed concentration of the $\mathrm{Ru}(\mathrm{II})$ complexes $(\sim 400 \mu \mathrm{M}$ for not irradiated and $\sim 80 \mu \mathrm{M}$ for irradiated compounds), gradually increasing the equivalents of the peptide through sequential addition of $1.0 \mu \mathrm{L}$ of different stock solutions $(2,10 \mathrm{mM})$ in water, kept at $0{ }^{\circ} \mathrm{C}$. Each spectrum was registered $(300-500 \mathrm{~nm})$ upon the addition of the peptide, after a stirring time of $2 \mathrm{~min}$. $\mathrm{EC}_{50}$ value was derived from non-linear regression of the data employing log (inhibitor) vs. response and "dose-response stimulation equation" of GraphPad program [57].

The solution stability of the three compounds in different buffers has been evaluated by collecting the UV/Vis spectra of the compounds in the presence of $10 \mathrm{mM}$ sodium citrate $(\mathrm{pH}=5.1)$, sodium acetate $(\mathrm{pH}=6.8)$ and sodium phosphate $(\mathrm{pH}=7.4)$ over $24 \mathrm{~h}$. The compounds have been dissolved in DMSO and then added to the selected buffers to reach a final concentration of $50 \mu \mathrm{M}$. The DMSO final concentration is less than $0.5 \%(v / v)$. UV/Vis spectra were registered on a Varian Cary $5000 \mathrm{UV}$-Vis spectrophotometer at room temperature, using $1 \mathrm{~cm}$ path length cuvettes and the following parameters: $300-500 \mathrm{~nm}$ range, $200 \mathrm{~nm} / \mathrm{min}, 2.0 \mathrm{~nm}$ bandwidth. The photoactivable CO-release properties of the compounds have been also analyzed by following the changes in the UV/Vis spectral profiles before and after $20 \mathrm{~min}$ of irradiation at $365 \mathrm{~nm}$ (see, for example, Figure S1 and Figure S2, where spectra of compound 1 are reported).

\subsection{ESI-MS Analysis}

Solutions of NPM1 $1_{264-277}$, at a concentration of $100 \mu \mathrm{M}$ in $10 \mathrm{mM}$ borate buffer at $\mathrm{pH}=9$, incubated with compound 2 in a molar ratio of 1:10 for $0 \mathrm{~h}$ and $24 \mathrm{~h}$ with and without UV irradiation, respectively, were diluted in ammonium acetate $15 \mathrm{mM}$ and analyzed by ESI-MS, as described in a previous work [56]. Raw mass spectra were processed by MaxEnt3 algorithm (MassLynx4.1, Micromass, Waters; Milford, MA, USA).

\section{Conclusions}

In this study we have carried out a biophysical investigation on the effect of three photoinduced $\mathrm{Ru}$ (II) dicarbonyl complexes on the self-aggregation of an amyloid model peptide, before and after irradiation at $365 \mathrm{~nm}$. Spectroscopic studies reveal that the three Ru compounds exhibit a strong modulatory effect on the amyloid-like aggregation of $\mathrm{NMP}_{264-277}$, both in the dark and upon the illumination.

ThT fluorescence time courses experiments indicate that the three compounds have a different behavior: compounds $\mathbf{1}$ and $\mathbf{2}$, functionalized with bidentate ligands, incorporating free coordination site close to the metal ion, promptly reduce the aggregation process, while compound 3, 
which does not incorporate close donor site, needs more time to induce reduction of aggregation. Electrospray ionization mass spectrometry and UV/Vis absorption spectroscopy experiments suggest that the mechanism of the modulation of aggregation is related to the formation of adducts formed upon reaction of the metal-based compounds with the peptide, through the binding of the peptide to the coordination sphere of $\mathrm{Ru}(\mathrm{II})$ ion that follows the release of the two coordinated $\mathrm{Cl}$ ions and one $\mathrm{CO}$ ligand. This mechanism of action explains why irradiated complexes are better than the non-irradiated compounds in modulating the aggregation of the amyloid sequence and provides a rationale to explain the different behavior of the three compounds observed in the ThT measurements: the absence of closer free coordination sites to $\mathrm{Ru}(\mathrm{II})$, and consequently the slower $\mathrm{CO}$ release, probably affects the kinetics of the formation of the Ru-fragment/peptide adduct causing a delay in its ability to modulate the aggregation of the peptide. On the other hand, the faster $\mathrm{CO}$ release of compound 1 , because of the presence of closely coordination-able free pyridyl arm, led to an improvement in the kinetics of inhibition in its irradiated form when compared to the non-irradiated molecule. This result suggests that a fine tuning of metal ligands could significantly affect the anti-amyloidogenic properties of metallodrugs and highlights the importance of a structural characterization of the adducts formed by reaction of metallodrugs with amyloid peptides.

Our data indicate that the investigated compounds are able to modulate the aggregation process of amyloid models in vitro and suggest an inhibitory mechanism that, however, needs future microscopy investigations to be confirmed.

In conclusion, the results here reported offer a valid support to the idea that photoactivatable metal carbonyl-based compounds may be successfully exploited or the treatment of neurodegenerative diseases.

Supplementary Materials: The following are available online at http:/www.mdpi.com/1424-8247/13/8/171/s1.

Author Contributions: A.M. and D.M. designed the concept. D.M. supervised the experiments. D.F., M.C., G.F., I.I., and M.M. performed the experimental work. A.M.M. synthesized and characterized the metal complexes. A.M. and D.M. wrote the manuscript. All authors have read and approved the final version of the manuscript.

Funding: This work was partially supported by POR CAMPANIA FESR 2014/2020 "Combattere la resistenza tumorale: piattaforma integrata multidisciplinare per un approccio tecnologico innovativo alle oncoterapie-Campania Oncoterapie" (Project N. B61G18000470007) to D. M.

Acknowledgments: We thank Consorzio Interuniversitario di Ricerca in Chimica dei Metalli nei Sistemi Biologici (C.I.R.C.M.S.B.).

Conflicts of Interest: The authors declare no conflict of interest.

\section{References}

1. Lin, K.; Zhao, Z.Z.; Bo, H.B.; Hao, X.J.; Wang, J.Q. Applications of Ruthenium Complex in Tumor Diagnosis and Therapy. Front. Pharmacol. 2018, 9, 1323. [CrossRef]

2. Moreno, V.; Font-Bardia, M.; Calvet, T.; Lorenzo, J.; Aviles, F.X.; Garcia, M.H.; Morais, T.S.; Valente, A.; Robalo, M.P. DNA interaction and cytotoxicity studies of new ruthenium(II) cyclopentadienyl derivative complexes containing heteroaromatic ligands. J. Inorg. Biochem. 2011, 105, 241-249. [CrossRef]

3. Liu, J.; Chen, Y.; Li, G.; Zhang, P.; Jin, C.; Zeng, L.; Ji, L.; Chao, H. Ruthenium(II) polypyridyl complexes as mitochondria-targeted two-photon photodynamic anticancer agents. Biomaterials 2015, 56, 140-153. [CrossRef]

4. Levina, A.; Mitra, A.; Lay, P.A. Recent developments in ruthenium anticancer drugs. Metallomics 2009, 1, 458-470. [CrossRef]

5. Merlino, A. Interactions of proteins and ruthenium compounds of medicinal interest: A structural perspective. Coord. Chem. Rev. 2016, 326, 111-134. [CrossRef]

6. Howerton, B.S.; Heidary, D.K.; Glazer, E.C. Strained ruthenium complexes are potent light-activated anticancer agents. J. Am. Chem. Soc. 2012, 134, 8324-8327. [CrossRef]

7. Li, F.; Collins, J.G.; Keene, F.R. Ruthenium complexes as antimicrobial agents. Chem. Soc. Rev. 2015, 44, 2529-2542. [CrossRef] 
8. Shum, J.; Leung, P.K.; Lo, K.K. Luminescent Ruthenium(II) Polypyridine Complexes for a Wide Variety of Biomolecular and Cellular Applications. Inorg. Chem. 2019, 58, 2231-2247. [CrossRef]

9. Chiti, F.; Dobson, C.M. Protein Misfolding, Amyloid Formation, and Human Disease: A Summary of Progress Over the Last Decade. Annu. Rev. Biochem. 2017, 86, 27-68. [CrossRef]

10. Chiti, F.; Dobson, C.M. Amyloid formation by globular proteins under native conditions. Nat. Chem. Biol. 2009, 5, 15-22. [CrossRef]

11. Hayne, D.J.; Lim, S.; Donnelly, P.S. Metal complexes designed to bind to amyloid-beta for the diagnosis and treatment of Alzheimer's disease. Chem. Soc. Rev. 2014, 43, 6701-6715. [CrossRef] [PubMed]

12. Spinello, A.; Bonsignore, R.; Barone, G.; Keppler, B.K.; Terenzi, A. Metal Ions and Metal Complexes in Alzheimer's Disease. Curr. Pharm. Des. 2016, 22, 3996-4010. [CrossRef]

13. Sava, G.; Capozzi, I.; Clerici, K.; Gagliardi, G.; Alessio, E.; Mestroni, G. Pharmacological control of lung metastases of solid tumours by a novel ruthenium complex. Clin. Exp. Metastasis 1998, 16, 371-379. [CrossRef]

14. Jakupec, M.A.; Arion, V.B.; Kapitza, S.; Reisner, E.; Eichinger, A.; Pongratz, M.; Marian, B.; Graf von Keyserlingk, N.; Keppler, B.K. KP1019 (FFC14A) from bench to bedside: Preclinical and early clinical development-an overview. Int. J. Clin. Pharmacol. Ther. 2005, 43, 595-596. [CrossRef] [PubMed]

15. Messori, L.; Camarri, M.; Ferraro, T.; Gabbiani, C.; Franceschini, D. Promising in Vitro anti-Alzheimer Properties for a Ruthenium(III) Complex. ACS Med. Chem. Lett. 2013, 4, 329-332. [CrossRef] [PubMed]

16. Huffman, S.E.; Yawson, G.K.; Fisher, S.S.; Bothwell, P.J.; Platt, D.C.; Jones, M.A.; Hamaker, C.G.; Webb, M.I. Ruthenium(iii) complexes containing thiazole-based ligands that modulate amyloid-beta aggregation. Metallomics 2020, 12, 491-503. [CrossRef] [PubMed]

17. Valensin, D.; Anzini, P.; Gaggelli, E.; Gaggelli, N.; Tamasi, G.; Cini, R.; Gabbiani, C.; Michelucci, E.; Messori, L.; Kozlowski, H.; et al. fac- $\{\mathrm{Ru}(\mathrm{CO})(3)\}(2+)$ selectively targets the histidine residues of the beta-amyloid peptide 1-28. Implications for new Alzheimer's disease treatments based on ruthenium complexes. Inorg. Chem. 2010, 49, 4720-4722. [CrossRef]

18. Chan, S.L.; Lu, L.; Lam, T.L.; Yan, S.C.; Leung, C.H.; Ma, D.L. A Novel Tetradentate Ruthenium(II) Complex Containing Tris(2- Pyridylmethyl)amine (tpa) As An Inhibitor Of Beta-amyloid Fibrillation. Curr. Alzheimer. Res. 2015, 12, 434-438. [CrossRef]

19. He, L.; Wang, X.; Zhao, C.; Wang, H.; Du, W. Ruthenium complexes as novel inhibitors of human islet amyloid polypeptide fibril formation. Metallomics 2013, 5, 1599-1603. [CrossRef]

20. Gong, G.; Xu, J.; Huang, X.; Du, W. Influence of methionine-ruthenium complex on the fibril formation of human islet amyloid polypeptide. J. Biol. Inorg. Chem. 2019, 24, 179-189. [CrossRef]

21. Gong, G.; Wang, W.; Du, W. Binuclear ruthenium complexes inhibit the fibril formation of human islet amyloid polypeptide. RSC Adv. 2017, 7, 18512-18522. [CrossRef]

22. Chatterjee, S.; Kundu, S.; Bhattacharyya, A.; Hartinger, C.G.; Dyson, P.J. The ruthenium(II)-arene compound RAPTA-C induces apoptosis in EAC cells through mitochondrial and p53-JNK pathways. J. Biol. Inorg. Chem. 2008, 13, 1149-1155. [CrossRef] [PubMed]

23. Finkelstein, A.E.; Walz, D.T.; Batista, V.; Mizraji, M.; Roisman, F.; Misher, A. Auranofin. New oral gold compound for treatment of rheumatoid arthritis. Ann. Rheum. Dis. 1976, 35, 251-257. [CrossRef] [PubMed]

24. Batchelor, L.K.; Ortiz, D.; Dyson, P.J. Histidine Targeting Heterobimetallic Ruthenium(II)-Gold(I) Complexes. Inorg. Chem. 2019, 58, 2501-2513. [CrossRef] [PubMed]

25. Ma, D.L.; He, H.Z.; Leung, K.H.; Chan, D.S.; Leung, C.H. Bioactive luminescent transition-metal complexes for biomedical applications. Angew Chem. Int. Ed. Engl. 2013, 52, 7666-7682. [CrossRef]

26. Cook, N.P.; Torres, V.; Jain, D.; Marti, A.A. Sensing amyloid-beta aggregation using luminescent dipyridophenazine ruthenium(II) complexes. J. Am. Chem. Soc. 2011, 133, 11121-11123. [CrossRef]

27. Babu, E.; Muthu Mareeswaran, P.; Sathish, V.; Singaravadivel, S.; Rajagopal, S. Sensing and inhibition of amyloid-beta based on the simple luminescent aptamer-ruthenium complex system. Talanta 2015, 134, 348-353. [CrossRef] [PubMed]

28. Yu, H.J.; Zhao, W.; Xie, M.; Li, X.; Sun, M.; He, J.; Wang, L.; Yu, L. Real-Time Monitoring of Self-Aggregation of beta-Amyloid by a Fluorescent Probe Based on Ruthenium Complex. Anal. Chem. 2020, 92, 2953-2960. [CrossRef]

29. Kenny, R.G.; Marmion, C.J. Toward Multi-Targeted Platinum and Ruthenium Drugs-A New Paradigm in Cancer Drug Treatment Regimens? Chem. Rev. 2019, 119, 1058-1137. [CrossRef] 
30. Pizarro, M.D.; Rodriguez, J.V.; Mamprin, M.E.; Fuller, B.J.; Mann, B.E.; Motterlini, R.; Guibert, E.E. Protective effects of a carbon monoxide-releasing molecule (CORM-3) during hepatic cold preservation. Cryobiology 2009, 58, 248-255. [CrossRef]

31. Caterino, M.; Petruk, A.A.; Vergara, A.; Ferraro, G.; Marasco, D.; Doctorovich, F.; Estrin, D.A.; Merlino, A. Mapping the protein-binding sites for iridium(iii)-based CO-releasing molecules. Dalton Trans. 2016, 45, 12206-12214. [CrossRef] [PubMed]

32. Pontillo, N.; Ferraro, G.; Messori, L.; Tamasi, G.; Merlino, A. Ru-Based CO releasing molecules with azole ligands: Interaction with proteins and the $\mathrm{CO}$ release mechanism disclosed by $\mathrm{X}$-ray crystallography. Dalton Trans. 2017, 46, 9621-9629. [CrossRef] [PubMed]

33. Kapetanaki, S.M.; Burton, M.J.; Basran, J.; Uragami, C.; Moody, P.C.E.; Mitcheson, J.S.; Schmid, R.; Davies, N.W.; Dorlet, P.; Vos, M.H.; et al. A mechanism for CO regulation of ion channels. Nat. Commun. 2018, 9, 907. [CrossRef] [PubMed]

34. Mansour, A.M.; Shehab, O.R. $\{\operatorname{Ru}(\mathrm{CO}) \mathrm{x}\}$-core terpyridine complexes: Lysozyme binding affinity, DNA and photoinduced carbon monoxide releasing properties. J. Photochem. Photobiol. Chem. 2018, 364, 406-414. [CrossRef]

35. Bani-Hani, M.G.; Greenstein, D.; Mann, B.E.; Green, C.J.; Motterlini, R. A carbon monoxide-releasing molecule (CORM-3) attenuates lipopolysaccharide- and interferon-gamma-induced inflammation in microglia. Pharmacol. Rep. 2006, 58, 132-144. [PubMed]

36. Schallner, N.; Schwemmers, S.; Schwer, C.I.; Froehlich, C.; Stoll, P.; Humar, M.; Pahl, H.L.; Hoetzel, A.; Loop, T.; Goebel, U. p38beta-regulated induction of the heat shock response by carbon monoxide releasing molecule CORM-2 mediates cytoprotection in lung cells in vitro. Eur. J. Pharmacol. 2011, 670, 58-66. [CrossRef]

37. Motterlini, R.; Mann, B.E.; Foresti, R. Therapeutic applications of carbon monoxide-releasing molecules. Exp. Opin. Investig. Drugs 2005, 14, 1305-1318. [CrossRef]

38. Ling, K.; Men, F.; Wang, W.C.; Zhou, Y.Q.; Zhang, H.W.; Ye, D.W. Carbon Monoxide and Its Controlled Release: Therapeutic Application, Detection, and Development of Carbon Monoxide Releasing Molecules (CORMs). J. Med. Chem. 2018, 61, 2611-2635. [CrossRef]

39. Brouard, S.; Otterbein, L.E.; Anrather, J.; Tobiasch, E.; Bach, F.H.; Choi, A.M.; Soares, M.P. Carbon monoxide generated by heme oxygenase 1 suppresses endothelial cell apoptosis. J. Exp. Med. 2000, 192, 1015-1026. [CrossRef] [PubMed]

40. Otterbein, L.E.; Bach, F.H.; Alam, J.; Soares, M.; Tao Lu, H.; Wysk, M.; Davis, R.J.; Flavell, R.A.; Choi, A.M. Carbon monoxide has anti-inflammatory effects involving the mitogen-activated protein kinase pathway. Nat. Med. 2000, 6, 422-428. [CrossRef]

41. Otterbein, L.E.; Zuckerbraun, B.S.; Haga, M.; Liu, F.; Song, R.; Usheva, A.; Stachulak, C.; Bodyak, N.; Smith, R.N.; Csizmadia, E.; et al. Carbon monoxide suppresses arteriosclerotic lesions associated with chronic graft rejection and with balloon injury. Nat. Med. 2003, 9, 183-190. [CrossRef] [PubMed]

42. Hettiarachchi, N.; Dallas, M.; Al-Owais, M.; Griffiths, H.; Hooper, N.; Scragg, J.; Boyle, J.; Peers, C. Heme oxygenase-1 protects against Alzheimer's amyloid-beta(1-42)-induced toxicity via carbon monoxide production. Cell Death Dis. 2014, 5, e1569. [CrossRef] [PubMed]

43. Hettiarachchi, N.T.; Boyle, J.P.; Dallas, M.L.; Al-Owais, M.M.; Scragg, J.L.; Peers, C. Heme oxygenase-1 derived carbon monoxide suppresses Abeta1-42 toxicity in astrocytes. Cell Death Dis. 2017, 8, e2884. [CrossRef] [PubMed]

44. De Simone, A.; Naldi, M.; Tedesco, D.; Milelli, A.; Bartolini, M.; Davani, L.; Widera, D.; Dallas, M.L.; Andrisano, V. Investigating in Vitro Amyloid Peptide 1-42 Aggregation: Impact of Higher Molecular Weight Stable Adducts. ACS Omega 2019, 4, 12308-12318. [CrossRef]

45. Scognamiglio, P.L.; Di Natale, C.; Leone, M.; Poletto, M.; Vitagliano, L.; Tell, G.; Marasco, D. G-quadruplex DNA recognition by nucleophosmin: New insights from protein dissection. Biochim. Biophys. Acta 2014, 1840, 2050-2059. [CrossRef]

46. Di Natale, C.; Scognamiglio, P.L.; Cascella, R.; Cecchi, C.; Russo, A.; Leone, M.; Penco, A.; Relini, A.; Federici, L.; Di Matteo, A.; et al. Nucleophosmin contains amyloidogenic regions that are able to form toxic aggregates under physiological conditions. FASEB J. 2015, 29, 3689-3701. [CrossRef] 
47. Russo, A.; Diaferia, C.; La Manna, S.; Giannini, C.; Sibillano, T.; Accardo, A.; Morelli, G.; Novellino, E.; Marasco, D. Insights into amyloid-like aggregation of $\mathrm{H} 2$ region of the C-terminal domain of nucleophosmin. Biochim. Biophys. Acta Proteins Proteom. 2017, 1865, 176-185. [CrossRef]

48. La Manna, S.; Roviello, V.; Scognamiglio, P.L.; Diaferia, C.; Giannini, C.; Sibillano, T.; Morelli, G.; Novellino, E.; Marasco, D. Amyloid fibers deriving from the aromatic core of C-terminal domain of nucleophosmin 1. Int. J. Biol. Macromol. 2019, 122, 517-525. [CrossRef]

49. Di Natale, C.; La Manna, S.; Malfitano, A.M.; Di Somma, S.; Florio, D.; Scognamiglio, P.L.; Novellino, E.; Netti, P.A.; Marasco, D. Structural insights into amyloid structures of the C-terminal region of nucleophosmin 1 in type A mutation of acute myeloid leukemia. Biochim. Biophys. Acta Proteins Proteom. 2019, 1867, 637-644. [CrossRef]

50. Scognamiglio, P.L.; Di Natale, C.; Leone, M.; Cascella, R.; Cecchi, C.; Lirussi, L.; Antoniali, G.; Riccardi, D.; Morelli, G.; Tell, G.; et al. Destabilisation, aggregation, toxicity and cytosolic mislocalisation of nucleophosmin regions associated with acute myeloid leukemia. Oncotarget 2016, 7, 59129-59143. [CrossRef]

51. La Manna, S.; Scognamiglio, P.L.; Roviello, V.; Borbone, F.; Florio, D.; Di Natale, C.; Bigi, A.; Cecchi, C.; Cascella, R.; Giannini, C.; et al. The acute myeloid leukemia-associated Nucleophosmin 1 gene mutations dictate amyloidogenicity of the C-terminal domain. FEBS J. 2019, 286, 2311-2328. [CrossRef] [PubMed]

52. Mansour, A.M.; Shehab, O.R. Photoactivatable CO-Releasing Properties of $\left\{\mathrm{Ru}(\mathrm{CO})_{2}\right\}$-Core Pyridylbenzimidazole Complexes and Reactivity towards Lysozyme. Eur. J. Inorg. Chem. 2017, 37, 4299-4310. [CrossRef]

53. Mansour, A.M. Ru ${ }^{\mathrm{II}}$-Carbonyl photoCORMs with N,N -Benzimidazole Bidentate Ligands: Spectroscopic, Lysozyme Binding Affinity, and Biological Activity Evaluation. Eur. J. Inorg. Chem. 2018, 7, 852-860. [CrossRef]

54. Florio, D.; Iacobucci, I.; Ferraro, G.; Mansour, A.M.; Morelli, G.; Monti, M.; Merlino, A.; Marasco, D. Role of the Metal Center in the Modulation of the Aggregation Process of Amyloid Model Systems by Square Planar Complexes Bearing 2-(2'-pyridyl)benzimidazole Ligands. Pharmaceuticals 2019, 12, 154. [CrossRef]

55. Florio, D.; Malfitano, A.M.; Di Somma, S.; Mugge, C.; Weigand, W.; Ferraro, G.; Iacobucci, I.; Monti, M.; Morelli, G.; Merlino, A.; et al. Platinum(II) O,S Complexes Inhibit the Aggregation of Amyloid Model Systems. Int. J. Mol. Sci. 2019, 20, 829. [CrossRef] [PubMed]

56. Giuffrida, M.L.; Grasso, G.; Ruvo, M.; Pedone, C.; Saporito, A.; Marasco, D.; Pignataro, B.; Cascio, C.; Copani, A.; Rizzarelli, E. Abeta(25-35) and its C- and/or N-blocked derivatives: Copper driven structural features and neurotoxicity. J. Neurosci. Res. 2007, 85, 623-633. [CrossRef]

57. Doti, N.; Scognamiglio, P.L.; Madonna, S.; Scarponi, C.; Ruvo, M.; Perretta, G.; Albanesi, C.; Marasco, D. New mimetic peptides of the kinase-inhibitory region (KIR) of SOCS1 through focused peptide libraries. Biochem. J. 2012, 443, 231-240. [CrossRef]

(C) 2020 by the authors. Licensee MDPI, Basel, Switzerland. This article is an open access article distributed under the terms and conditions of the Creative Commons Attribution (CC BY) license (http://creativecommons.org/licenses/by/4.0/). 